\title{
Peran influencer dalam proses electronic word of mouth untuk meningkatkan persepsi merek
}

\author{
Chiquita Olivia Riama \\ Universitas Indonesia, Jakarta, Indonesia
}

\begin{abstract}
ABSTRAK
Word of mouth (WOM) sejak dahulu dinilai sebagai sumber informasi utama dan paling penting dalam keputusan konsumen untuk mengonsumsi sesuatu. Pada era globalisasi, WOM berkembang menjadi bentuk yang lebih masif namun tetap interpersonal, yang disebut sebagai electronic word of mouth (eWOM). Perkembangan internet yang memungkinkan terbentuknya platform media sosial seperti Instagram telah menciptakan kesempatan baru bagi perkembangan eWOM sebagai bagian dari promosi bisnis. Ketika sebuah eWOM tentang sebuah produk berjalan positif, secara langsung akan memengaruhi persepsi merek (brand perception) secara positif pula. Salah satu konsep yang terkait dengan pembentukan eWOM dan persepsi merek pada media sosial Instagram saat ini adalah influencer. Tujuan dari penelitian ini yaitu untuk mengetahui bagaimana peran influencer media sosial dalam proses pembentukan eWOM positif sehingga mampu berdampak pada peningkatan persepsi merek. Penelitian ini menggunakan metode kualitatif, dengan pengumpulan data lewat kajian pustaka dan wawancara mendalam dengan seorang pemilik usaha Celosia Etnik yang aktif melakukan promosi di Instagram. Untuk tujuan tersebut, peneliti mencoba membedah data dari hasil wawancara mendalam lewat dimensi-dimensi eWOM dan dipandu pula dengan Teori Kredibilitas Sumber (Source Credibility Theory/SCT). Berdasarkan penelitian ini, diketahui bahwa influencer dengan kredibilitas yang tinggi sangat besar perannya dalam pembentukan eWOM positif terkait produk yang dipromosikan. Dengan eWOM positif, maka secara langsung akan meningkatkan nilai positif pada persepsi merek di masyarakat. Hal ini berarti, keberhasilan influencer mampu membuat khalayak memahami informasi tentang produk dan ingin membelinya. Implikasi secara teoritis dan praktis, serta rekomendasi untuk penelitian di masa depan akan dibahas lebih dalam pada artikel ini.
\end{abstract}

Kata-kata kunci: eWOM; media sosial; influencer; persepsi merek; teori kredibilitas sumber

\section{Influencers' role in electronic word of mouth process to increase brand perception \\ ABSTRACT}

\begin{abstract}
Word of mouth (WOM) has long been regarded as the main source of information in consumers' purchase intention. In the globalization era, WOM developed into a massive but still interpersonal form, which referred as electronic word of mouth (eWOM). The development of the internet, that has enabled the formation of social media platforms like Instagram, has created new opportunities for the development of eWOM for business promotion. When an eWOM about a product runs positively, will directly affect brand perception positively. Nowadays, one of the concepts related to the formation of eWOM and brand perception on social media is influencer. The aim of this study is to explore about what role the social media influencer has in forming positive eWOM that can affect brand perception. This study uses a qualitative method, by collecting data through literature review and in-depth interviews with Celosia Ethnic business owners who are actively conducting promotions on Instagram. For this purpose, the researcher tries to process the interviews result through the eWOM dimensions and also guided by the Source Credibility Theory (SCT). Based on this research, it is known that influencers with high credibility have a big role in the positive products' $\mathrm{eWOM}$. With positive eWOM, it will directly form a good brand perception from the society. It means, the success of influencers is when they able to make the audience understand about the product and increase the purchase intention. Theoretical and practical implications, also recommendations for future research will be discussed deeply in this article.
\end{abstract}

Keywords: eWOM; social media; influencer; brand perception; source credibility theory (SCT)

Korespondensi: Chiquita Olivia Riama, S.I.Kom. Universitas Indonesia. Jl. Salemba Raya No.4, RW.5, Kenari, Kec. Senen, Kota Jakarta Pusat, Daerah Khusus Ibukota Jakarta 10430. Email: chiquitaorh15@ gmail.com 


\section{PENDAHULUAN}

Kehadiran digitalisasi komunikasi membuat perubahan signifikan pada budaya komunikasi masyarakat. McMullan (2020) menjelaskan, proses digitalisasi mampu membentuk budaya komunikasi dan hubungan sosial yang berbeda pula. Hadirnya internet sebagai meta-medium adalah langkah awal perkembangan teknologi komunikasi digital. Proses komunikasi yang terfasilitasi oleh internet ini memiliki sifat utama, yaitu reproducibility, yang berkaitan langsung dengan bentuk user generated content. Duffy (2015) menjelaskan user generated content sebagai konten yang dibuat oleh pengguna (user), dan pada akhirnya mampu memproduksi informasi bersifat homogen. Adanya skema user generated content menjadi pemicu utama bentuk interaksi dan kolaborasi yang lebih luas antar pengguna internet. Hal ini mendorong kemudahan untuk berbagi opini dan bertukar pengalaman di antara pengguna (Olmedilla et al., 2016). Pada akhirnya, interaksi elektronik yang difasilitasi oleh internet ini melengkapi bentuk komunikasi dari mulut ke mulut atau word of mouth (WOM).

Bentuk WOM merupakan penyampaian informasi yang tertua, dimana dikaitkan dengan bentuknya yang dipertimbangkan sebagai medium terpecaya, bahkan jika dibandingkan dengan media massa (Huete-Alcocer, 2017).
Definisi awal mengenai WOM salah satunya dicetuskan oleh Katz \& Lazarsfeld (1966), yang menjelaskan bentuk ini sebagai pertukaran informasi pemasaran antara para konsumen dan menjadi dasar dalam pembentukan sikap dan pilihan konsumen terhadap sebuah produk. Informasi dari WOM bisa dikatakan menjadi sumber informasi utama dan paling penting dalam keputusan konsumen untuk mengonsumsi sesuatu (Huete-Alcocer, 2017). Proses komunikasi yang disoroti dalam hal ini, mencakup hubungan antara perusahaan merek dan konsumennya, di mana WOM dipercaya memiliki pengaruh sangat besar dalam intensi seseorang dalam membeli dan bisa dilihat sebagai prediktor baik (WOM positif) atau buruk (WOM negatif) (Talwar et al., 2020) fsebuah merek dan perusahaan.

Pada era globalisasi ini, WOM telah berkembangmenjadibentukyanglebihmasifdan tidak terhalang kondisi geografis, namun tetap interpersonal, yang kemudian disebut sebagai electronic word of mouth (eWOM) (Law et al., 2014; Yang, 2017). Internet kini menyediakan beberapa platform untuk terciptanya eWOM seperti media sosial, blog, situs ulasan (review websites), hingga situs belanja (Cheung \& Thadani, 2012). Informasi melalui eWOM bisa dikatakan paling efektif, karena masyarakat cenderung mempercayai informasi yang didapat dari sesama konsumen dibandingkan 
dari perusahaan yang memproduksi produk atau layanan (Nieto et al., 2014). Hal ini juga terjadi di tengah masyarakat Indonesia.

Hasil survey Asosiasi Penyelenggara Jasa Internet Indonesia (APJII) 2019, dari total populasi sebesar 264 juta penduduk Indonesia, sebanyak 171,17 juta penduduk (64,8 persen) sudah terhubung ke internet. Angka ini meningkat dari tahun 2017 yang sebesar 54,86 persen. Sebagai hasil dari proses kognisi sosialnya, masyarakat Indonesia cenderung memiliki budaya berbagi (share) saat berada di media sosial (Mulawarman \& Nurfitri, 2017). Selain itu, salah satu bentuk kegiatan yang juga cukup tinggi dilakukan oleh masyarakat Indonesia terkait dengan media sosial adalah belanja daring (Mulawarman \& Nurfitri, 2017). Misalnya, situs pertemanan seperti Facebook dan Instagram yang fungsi awalnya adalah sebagai media pertukaran informasi dengan sesama rekan pengguna, saat ini bisa dikatakan berganti fungsinya sebagai wadah pemasaran produk. Masyarakat Indonesia pun akhirnya terbiasa mencari informasi terkait produk lewat media sosial.

Jika dahulu seseorang melakukan WOM dari orang-orang terdekat untuk menggali informasi, saat ini pengguna internet mencari informasi lewat komentar daring mengenai produk atau layanan tertentu (Nieto et al., 2014). Bisa pula terjadi kondisi di mana seseorang atau konsumen mendapat rekomendasi melalui WOM, yang sebelumnya merupakan rekomendasi yang didapat secara daring (eWOM) (Kassim \& Asiah Abdullah, 2010). Platform yang tersedia di internet saat ini menghadirkan wadah bagi konsumen untuk melakukan diskusi dan bertukar informasi mengenai sebuah produk, serta belajar dari pengguna lain mengenai penggunaan produk tersebut (King et al., 2014). Informasi-informasi yang didapat tersebut menjadi dasar pemilihan apakah seseorang akan mengonsumsi produk atau jasa tersebut.

Bentuk eWOM bisa dikatakan sebagai sumber informasi terkait merek, terlebih di dunia digital saat ini, sehingga kredibilitas ulasan atau informasi yang diberikan perlu dipertanyakan (Lin \& Xu, 2017). Olshavsky \& Rosen (1985) menyatakan, konsumen akan lebih tertarik pada produk atau layanan ketika informasi awal yang mereka dapatkan memuaskan kebutuhan mereka. Hal tersebut menuntun pada konsep berikutnya terkait kekuatan informasi sebuah pesan atau pemasaran lewat eWOM, yaitu influencer (pemengaruh). High-level reviewer (dalam hal ini influencer) adalah mereka yang berkontribusi secara aktif dalam penyebaran informasi produk dalam kategori atau domain tertentu (Olmedilla et al., 2016). Konsumen akan lebih menaruh perhatiannya pada pengulas yang mempunyai terpaan tinggi 
yang juga merupakan konsumen (seperti ulasan daring/online review), karena dianggap lebih persuasif dan dapat dipercaya, dan terutama penting dalam lingkungan daring (Maslowska et al., 2017). Informasi mengenai produk dan jasa yang dipasarkan sebuah perusahaan dapat disebarluaskan lebih cepat serta dipromosikan secara lebih baik lewat rekomendasi dan ulasan yang diberikan influencer kepada pengikut (follower) dan rekan mereka (Cheung \& Thadani, 2012). Salah satu bentuk identifikasi seseorang sebagai influencer difokuskan pada munculnya ide mengenai kepercayaan (Kim \& Tran, 2013) dan keahlian dalam bidang tertentu (Ku et al., 2012). Mereka yang bisa dikatakan sebagai pemimpin opini, dimana ulasannya cenderung dicari karena mereka dianggap memiliki banyak pengetahuan sesuai bidang keahlian yang dituju dan dianggap memiliki pandangan inovatif (Casaló et al., 2020).

Penggunaan influencer dalam kaitannya dengan konsep eWOM memiliki peran penting dan menarik bagi pemain bisnis karena pentingnya dampak ulasan mereka yang mampu memengaruhi niat beli konsumen (Olmedilla et al., 2016). Di Indonesia sendiri, salah satu kinerja influencer yang paling sering kita temukan adalah promosi (endorsement). Promosi yang dilakukan oleh influencer lebih bisa diterima oleh masyarakat karena orangorang merasa lebih "dekat" dan "mirip" sehingga lebih efektif (Schouten et al., 2019) dan untuk meningkatkan perilaku pembelian produk (Carlson \& Donavan, 2013).

Secara teoritis, dapat dilihat bahwa ketika influencer melakukan promosi, maka pada waktu yang relatif cepat, informasi produk tersebut akan menjadi eWOM lewat kolom komentar serta fitur share yang bisa dilakukan dalam sosial media. Informasiinformasi tersebut akan membentuk eWOM dan akhirnya memengaruhi persepsi merek. Persepsi merek merupakan variabel signifikan untuk membangun loyalitas dan kecenderungan terhadap merek (Tengblad-Kreft et al., 2017). Kapferer (2012) menjelaskan, merek adalah serangkaian persepsi yang ditambahkan pada konsumen. Goodman et al. (2011) berpendapat bahwa influencer memiliki kekuatan yang signifikan terhadap terbentuknya persepsi pada sebuah merek. Persepsi merek berbeda dengan konstruksi pemasaran, lebih cenderung pada apa yang dipikirkan atau dirasakan konsumen mengenai sebuah merek atau bentuk kolektif dari semua interaksi dan pengalaman konsumen yang berkaitan dengan sebuah merek (Aiswarya \& Krishnan, 2019). Ketika seseorang memiliki persepsi merek secara positif dan melakukan pembelian, maka tujuan komunikasi sebuah perusahaan bisa dikatakan berhasil. Maka, persepsi merek ini perlu dikaji sebagai hasil dari eWOM dan kaitannya dengan influencer. 
Salah satu merek yang aktif dalam melakukan promosi daring adalah Celosia Etnik (@celosiaetnik). Celosia Etnik merupakan merek pakaian wanita yang berbasis produk lokal, di mana pengerjaannya dilakukan oleh pekerja rumahan. Celosia Etnik yang didirikan oleh Valeria Nisatama (26 tahun) masih menggunakan platform Instagram dalam pemasarannya. Merek ini juga kerap bekerja sama dengan influencer di Instagram untuk mengenakansetproduk danmempromosikannya pada akun pribadi mereka. Menurut beberapa unggahan dari Instagram pemilik (Valeria Nisatama) dan Instagram bisnisnya, permintaan pertemanan yang masuk pada akun @ celosiaetnik terus-menerus meningkat, salah satunya karena keaktifan Celosia Etnik dalam melakukan promosi daring.

Selain mengumpulkan berbagai informasi dari literatur, wawancara dilakukan untuk melengkapi data. Penting bagi para pemain bisnis atau perusahaan untuk menjalin kerjasama dengan influencer dalam meningkatkan kualitas hubungannya dengan konsumen. Hal ini karena influencer bisa menciptakan komunitas virtual. Penelitian sebelumnya terkait persepsi merek menunjukkan, konsumen tidak hanya memiliki perhatian pada fitur dari merek tetapi juga aspek relasional dan emosionalnya dengan produk (Aiswarya \& Krishnan, 2019). Untuk mendapatkan pengalaman yang baik secara daring, perusahaan perlu menciptakan komunitas untuk membangun hubungan kuat dengan konsumen dan memudahkan konsumen untuk mengonsumsi apa yang mereka produksi, di mana nilai tambahnya terletak pada terbentuknya hubungan konsumen yang semakin interaktif dan eksperiensial terhadap produk (Dessart et al., 2015)

Tujuan penelitian ini adalah mengkaji bagaimana peran influencer dalam proses eWOM sehingga mampu meningkatkan persepsi merek, berdasarkan dimensi-dimensi pada eWOM positif. Peneliti menggunakan Teori Kredibilitas Sumber (the source credibility theory/SCT) untuk menuntun pembahasan. Teori ini berkaitan erat pula dalam dunia periklanan. Dalam Umeogu (2012) dijelaskan mengenai tujuan utama pengiklan mau membayar dengan harga tinggi dalam kesepakatan promosi, yaitu karena para bintang, model, dan selebritas diasumsikan sebagai role model di mata para konsumen yang sehari-harinya berkeinginan untuk bisa seperti mereka. Sehingga teori ini membantu membuktikan apakah memang penggunaan influencer bisa meningkatkan persepsi merek sebuah produk, dikaji dari hasil wawancara dengan Valeria, pemilik Celosia Etnik.

Pada penelitian ini, peneliti juga hendak melihat kemungkinan pekerjaan influencer beririsan dengan pekerjaan public relations 
(PR). Saat ini, perusahaan dihadapkan dengan keadaan bahwa salah satu aktivitas penting yang harus dilakukan perusahaan adalah membangun hubungan jangka panjang dengan influencer, karena hal ini membuat konsumen lebih sadar dan peduli terhadap sebuah merek (Uzunoğlu \& Misci Kip, 2014). PR bahkan bisa dikatakan lebih kredibel jika dibandingkan dengan bentuk iklan, karena bentuk narasi menarik yang disusun akan mampu memikat konsumen, sehingga penting bagi perusahaan atau organisasi untuk terhubung dengan konsumen dan pemangku kepentingan melalui story telling (Ismail \& Ahmad, 2015). Hal inilah yang membuat PR sangat kuat dalam meningkatkan kesadaran publik (public awareness). Maka diperlukan sebuah kajian khusus apakah yang dilakukan PR mampu dilakukan sepenuhnya oleh influencer.

Chakraborty \& Bhat (2018) pernah melakukan penelitian bahwa kredibilitas sumber (dalam hal ini influencer) yang memberikan ulasan secara daring dan kualitas ulasannya merupakan prediktor dari ulasan yang akan dimaknai oleh konsumen, yang mana sangat memengaruhi kesadaran merek (brand awareness) dan niat pembelian. Kesadaran (awareness) dan kepercayaan (trust) adalah konsep yang terdapat dalam persepsi merek, yang juga merupakan salah satu tujuan utama pekerjaan PR. Namun, dengan hadirnya influencer, pekerjaan kompleks PR bisa disederhanakan dan persepsi merek bisa terbentuk. Maka sebagai studi di masa depan, ada potensi persinggungan pekerjaan antara PR dan influencer.

\section{METODE PENELITIAN}

Penelitian ini merupakan penelitian berparadigma konstruktivisme. Paradigma konstruktivisme dipilih berdasarkan tujuan penelitian yang ingin mengetahui bagaimana peran influencer dalam proses eWOM untuk meningkatkan persepsi merek. Dalam paradigma konstruktivisme, teori tidak mendahului penelitian tetapi mengikutinya sehingga berpijak pada data yang dihasilkan ketika penelitian penelitian berlangsung (Strauss \& Corbin, 1990). Paradigma konstruktivisme membuat peneliti fokus pada pengalaman unik individu (Kelly et al., 2018).

Berdasarkan paradigma tersebut, peneliti menggunakan pendekatan kualitatif. Menurut Moleong (2004), penelitian kualitatif mampu melihat kenyataan ganda, serta lebih peka terhadap kemungkinan-kemungkinan dan pola-pola nilai beragam yang akan muncul dalam penelitian. Hasil penelitian kualitatif lebih menekankan makna daripada generalisasi (Sugiyono, 2012). Hal ini sejalan dengan bagaimana peneliti akan mensintesis konsep terkait influencer, eWOM, dan persepsi merek 
lewat pengalaman pemilik toko daring (online store). Penelitian kualitatif cenderung tidak berstruktur, konsep-konsep yang digunakan bisa merupakan konsep yang belum memperoleh definisi dan dijabarkan secara ketat (tak jarang menggunakan sensitizing concept, yang berfungsi hanya sebagai gambaran konseptual umum dan awal), perumusan permasalahan yang akan diteliti juga harus ditemukan setelah melakukan pengumpulan data.

Metode yang digunakan dalam penelitian ini adalah fenomenologi deskriptif. Fenomenologi deskriptif, yang banyak digunakan dalam penelitian ilmu sosial, didefinisi sebagai metode untuk mengeksplorasi dan mendeskripsi pengalaman hidup secara individu (Christensen et al., 2017). Pada metode ini peneliti menjadikan manusia sebagai subjek penelitian, dimana peneliti akan melihat bagaimana fenomena influencer dalam proses eWOM terhadap peningkatan kesadaran merek, dari segi pemilik merek. Pengumpulan data terdiri dari 2 bagian utama, yaitu tinjauan pustaka dan kemudian dilengkapi dengan wawancara. Tinjauan pustaka merupakan cara untuk mengumpulkan data dari berbagai sumber yang terkait dengan penelitian yang bisa didapat dari jurnal ilmiah, buku, dan internet (Setyorini \& Irwansyah, 2018). Penggunaan tinjauan pustaka secara benar dan efektif sebagai metode penelitian mampu menjadi dasar yang kokoh untuk meningkatkan pengetahuan serta mendukung pengembangan teori (Webster \& Watson, 2002). Tinjauan pustaka adalah cara yang tepat untuk melakukan sintesis dari temuan-temuan penelitian sebelumnya, serta mampu mengungkap bagian-bagian yang butuh dilakukan penelitian lebih lanjut (Snyder, 2019).

Wawancara dilakukan peneliti untuk melengkapi penelitian dengan pengalaman individu pada situasi yang sebenarnya. Hal ini membantu untuk memahami secara lebih luas konsep yang dibangun peneliti, bukan hanya secara teori, melainkan secara praktik dalam kehidupan nyata. Setelah mengumpulan datadata terkait influencer, eWOM, dan persepsi merek, peneliti mulai menyusun pertanyaan wawancara untuk diajukan kepada narasumber. Pemahaman peneliti dibangun bersama dengan informan lewat interaksi dialog saat pencarian data melalui wawancara (Given, 2008). Wawancara ini dirasa tepat oleh peneliti agar bisa mendapatkan informasi yang lebih nyata pada kondisi yang sebenarnya. Peneliti memahami bahwa kondisi sebenarnya tidak akan sestabil teori dan konsep sehingga perlu dilengkapi dengan wawancara. Wawancara dilakukan dengan narasumber yang menggeluti bisnis daring dan aktif menggunakan influencer dalam mempromosikan merek. Informan yang dipilih peneliti adalah Valeria Nisatama, pemilik merek Celosia Etnik (@celosiaetnik). 
Hasil wawancara tersebut kemudian di-coding berdasarkan dimensi karakteristik eWOM dan acuan lain terkait influencer. Dengan catatan, peneliti ingin melihat dari segi pelaku bisnis, apakah eWOM yang terjadi memang memiliki pengaruh pada bisnis yang dijalankan Celosia Etnik dan memengaruhi persepsi merek: produk diketahui secara benar dan juga meningkatkan keinginan untuk membeli.

\section{HASIL DAN PEMBAHASAN}

Penelitian ini hadir untuk mengeksplorasi bagaimana peran influencer dalam proses eWOM sehingga akhirnya mampu memengaruhi persepsi merek. Lebih tepatnya, studi ini berfokus pada efek informasi produk yang diberikan oleh influencer kepada pengikut mereka sehingga memicu terjadinya eWOM. Sehingga, pada akhirnya hasil eWOM memberikan pengaruh pada persepsi merek.

Penelitian sebelumnya menunjukkan bahwa pengaruh eWOM signifikan dengan minat membeli (Mehyar et al., 2020) dan terpenuhnya informasi untuk masyarakat terhadap produk tertentu - dimana di awal pengenalan terhadap produk, konsumen akan memperhatikan apakah mereka memiliki relasi dengan komunikator eWOM sehingga berpotensi mengurangi risiko pembelian produk yang tidak sesuai dengan kebutuhan mereka (Rosario et al., 2016). Beberapa platform saat ini, salah satunya Instagram, menghadirkan fitur yang membantu terbentuknya proses eWOM. Dalam Instagram misalnya, seseorang bisa mengunggah foto produk dari berbagai sisi secara detail, serta menuliskan informasi yang lebih lengkap pada bagian caption sebagai bentuk ulasan. Selanjutnya, pada Instagram juga terdapat fitur likes dan comment sehingga sebuah foto bisa dinilai terpaannya. Instagram kini menjadi salah satu alat pembentuk eWOM menyediakan wadah bagi para pelanggan untuk melakukan diskusi mengenai produk dan mempelajari produk tersebut dari pelanggan lainnya mengenai bagaimana cara menggunakan produk tersebut (King et al., 2014).

Ulasan daring biasanya mencakup aspekaspek seperti teks berisi komentar tentang produk, peringkat produk dan penilaian, dan kalimat-kalimat kunci pendukung yang terkait dengan kelemahan dankekuatan yang dihadirkan dari produk. Selain itu, reputasi yang memberi ulasan memungkinkan untuk menambahkan kepercayaan bagi orang lain sebagai calon pembeli (Ku et al., 2012). Seperti yang sudah dijelaskan peneliti sebelumnya, yang merupakan variabel signifikan untuk membangun loyalitas dan kecenderungan terhadap merek adalah persepsi merek (Tengblad-Kreft et al., 2017). Persepsi merek bisa dikatakan sebagai bentuk kolektif dari semua interaksi dan pengalaman konsumen yang berkaitan dengan 
sebuah merek. Aiswarya \& Krishnan (2019) menjelaskan, persepsi merek lebih mengacu pada tingkatan di mana konsumen mampu mengenali produk atau layanan sebuah merek sehingga akhirnya memengaruhi kepercayaan mereka dan menentukan keinginan untuk melakukan pembelian di kemudian hari. Hal ini bisa dilihat dari sejauh mana konsumen dapat mengasosiasikan secara tepat sebuah merek dengan fungsi produk. Hal ini berarti penelitian akan berfokus pada proses komunikasi, dan bukan pemasarannya.

Mengenai pengaruh eWOM bagi persepsi merek ini dikaji melalui dimensi karakteristik eWOM yang selama ini dihasilkan ketika Valeria berkerja sama dengan influencer. Peneliti merangkum dimensi karakteristik eWOM positif, serta untuk melengkapi pembahasan, peneliti juga akan membahas hasil penelitian dibantu dengan Teori Kredibilitas Sumber.

Menurut keterangan Valeria, Celosia Etnik merupakan merek pakaian wanita yang memajukan nuansa etnik pada setiap desainnya. Wanita berusia 26 tahun ini mengawali usahanya lewat media sosial Instagram sejak 25 Mei 2016. Hingga saat ini, Instagram@celosiaetnik sudah memiliki lebih dari 77 ribu pengikut aktif. Hasil wawancara mendalam menunjukkan, bagi pelaku bisnis daring, persepsi merek memengaruhi penjualan (Wawancara dengan $\mathrm{V}$. Nisatama 29 Mei 2020). Maka, semakin banyak orang yang memperbincangkan merek akan mempermudah para pelaku bisnis tersebut untuk melakukan promosi. Bagi bisnis yang dijalankan Valeria, promosi dari mulut ke mulut adalah salah satu strategi utama dalam pengembangan

\section{Tabel 1 Konsep dan Teori}

\begin{tabular}{ccl}
\hline No & Konsep / Teori & \multicolumn{1}{c}{ Dimensi } \\
\hline 1 & eWOM positif & Message-involvement (Dichter, 1966; Jeong \& Jang, \\
& 2012 ) \\
& Concern for others (Engel et al., 1993; Jeong \& Jang, \\
& 2011 ) \\
& Helping the Company (Jeong \& Jang, 2011; Sundaram \\
& et al., 1998) \\
& Platform Assistance (Hasan, 2015; Jeong \& Jang, 2011) \\
& Relevance (Lugina, 2015) \\
& Timeliness (Lugina, 2015) \\
& Accuracy (Lugina, 2015) \\
& Comprehensiveness (Lugina, 2015) \\
& Keahlian (expertise) (Rahim et al., 2016) \\
& Kepercayaan (trustworthiness) (Rahim et al., 2016) \\
&
\end{tabular}


bisnisnya. Informasi yang diharapkan muncul sebagai perbincangan bagi masyarakat adalah eWOM positif yang meningkatkan citra baik bagi merek tersebut. Salah satu prinsipnya yaitu konsumen akan tertarik jika teman terdekat atau keluarga yang mereka percayalah yang mempromosikan barang tersebut (Wawancara dengan V. Nisatama 29 Mei 2020).

Hal ini sejalan dengan dimensi eWOM mengenai message-involvement. Dari sisi pelaku bisnis, dimensi ini sangat penting untuk terjadi dalam proses eWOM terkait merek mereka. Dichter (1966) menjelaskan, messageinvolvement ini terkait dengan munculnya diskusi yang distimulasi dengan adanya iklan atau kegiatan PR. Dalam hal ini, pelaku bisnis menginginkan dimensi ini terjadi secara positif karena pada akhirnya akan membantu meningkatkan kepercayaan masyarakat terhadap merek tersebut. Ekspresi perasaan positif ini dipicu oleh pengalaman konsumsi yang positif (Hasan, 2015). Oleh sebab itu, eWOM positif dari diskusi para pelanggan ini bisa berperan sebagai bentuk pengendalian mutu (quality control). Menurut Valeria, ketika suatu saat muncul komentar negatif, hal ini secara cepat juga membantu pelaku bisnis untuk melakukan perbaikan sehingga tidak ada lagi keluhan (complaint) di kemudian hari.

Dimensi berikutnya yang juga diharapkan muncul dalam proses eWOM dalam meningkatkan persepsi merek adalah concern for others. Dimensi ini menunjukkan keinginan tulus untuk membantu orang lain agar mereka memiliki keputusan membeli yang baik (Engel et al., 1993; Jeong \& Jang, 2011). Selain itu, dimensi ini menunjukkan keinginan untuk berbagi pengalaman positif antar konsumen. "Salah satu hal yang penting adalah bagaimana pelanggan kita itu bisa benar-benar jatuh cinta sama produk kita, dan akhirnya timbul keinginan sendiri untuk sharing sama orangorang sekitar untuk mau membeli produk kita. Kalau seperti itu, artinya promosi kita berhasil banget," jelas Valeria.

Pembicaraan dari mulut ke mulut adalah hal penting bagi bisnis, khususnya yang berbasis penjualan daring. Salah satu pencapaian yang diinginkan oleh pelaku bisnis, selain tentu saja produknya laku di pasaran, adalah juga keaktifan dari para pelanggan. Karakteristik pengikut@celosiaetnik saat ini adalah generasi milenial dan ibu-ibu muda (18-35 tahun), aktif memberikan testimonial (review), dan aktif menanyakan ketersediaan stok (wawancara dengan V. Nisatama 29 Mei 2020). Hal ini berarti sejalan dengan dimensi eWOM positif yaitu platform assistance, di mana bisa dilihat hasilnya dari dua hal, yaitu frekuensi kunjungan konsumen pada platform dan komentar yang ditinggalkan konsumen pada platform (Hasan, 2015; Jeong \& Jang, 2011). EWOM berjalan 
positif jika keduanya terjadi, dan hal tersebut dirasa sangat membantu pengembangan bisnis bagi Celosia Etnik. Pada akhirnya, kesan positif yang terbentuk secara mandiri pada masyarakat menumbuhkan keinginan untuk melakukan rekomendasi pada orang lain. Hal ini tentu secara tidak langsung sangat membantu memajukan bisnis sesuai dengan dimensi helping the company (Jeong \& Jang, 2011; Sundaram et al., 1998).

Menurut Valeria, sangat penting untuk menyampaikan informasi secara akurat mengenai produk yang diperdagangkan pada pembeli. Apalagi, ketika bisnis dilakukan secara daring, maka pelanggan tidak memiliki kemampuan untuk mendapatkan pengalaman langsung dalam melihat, menyentuh, dan mencoba bentuk fisik dari produk tersebut. "Review itu sangat penting, dengan adanya honest review membantu promosi juga secara tidak langsung dan konsumen lain menjadi tidak ragu untuk membeli," jelas Valeria. Hal ini berkaitan erat dengan dengan dimensi accuracy pada eWOM. Dimensi ini menjelasan mengenai keandalan sebuah informasi, bagaimana seseorang dapat menerima informasi secara benar dalam proses eWOM (Lugina, 2015). Dengan penyampaian informasi produk secara akurat, pembeli mampu membuat gambaran sendiri mengenai bagaimana kualitas produk tersebut dan percaya untuk melakukan pembayaran. Ketika sebuah informasi sudah akurat, maka dimensi eWOM berikutnya yang terjadi yaitu relevance, di mana dimensi ini menunjukkan seberapa validnya pesan sampai akhirnya digunakan untuk mengambil keputusan (Lugina, 2015). Selain itu, eWOM juga terfasilitasi dengan karakteristik media sosial yang serba cepat dan terintegrasi. Dimensi timeliness, yang menunjukkan seberapa cepat pesan tersebar sesuai dengan kebaruannya (Lugina, 2015), juga berdampak positif bagi penyebaran informasi produk, apalagi ketika sebuah bisnis mengeluarkan produk baru. Dalam hitungan detik, informasi mengenai produk baru tersebut akan diterima masyarakat. Namun meskipun tergolong cepat, fitur media sosial Instagram tetap memungkinkan eWOM berjalan dalam dimensi comprehensiveness, atau seberapa lengkap informasi yang ditangkap seseorang (Lugina, 2015).

Peneliti menemukan bahwa yang diinginkan pelaku bisnis adalah terjadinya eWOM positif. Dengan demikian, salah satu kuncinya adalah pesan harus bersumber dari sumber yang kredibel. Dalam studi ini, influencer digolongkan dalam komunikator eWOM karena mereka lah yang secara langsung melakukan penyampaian pesan kepada khalayak. Menurut Valeria dalam wawancara yang dilakukan dengan peneliti, influencer sebagai endorser produk Celosia Etnik memiliki peran yang signifikan terhadap 
perkembangan bisnisnya. Salah satu yang menjadi acuannya dalam menilai hal ini adalah semakin tingginya keterikatan (engagement) dengan khalayak, seperti meningkatnya jumah pengikut. "(Influencer) termasuk yang berpengaruh, karena pernah ada influencer yang membeli produk saya dan mempromosikannya sehingga terjadi pertambahan 4000 follower," jelas Valeria. Valeria juga menyatakan, efektivitas penggunaan endorser ini juga terlihat dari cara konsumen memesan produknya. Beberapa konsumen menyebut nama influencer tertentu untuk merujuk pada baju yang mereka inginkan. Maka, dapat dikatakan dalam proses ini sudah terjadi eWOM positif, selain produk dikenal, para calon konsumen juga mau melakukan pembelian.

Menurut Valeria, kualitas influencer menjadi pertimbangan besar karena menentukan keberhasilan. Selain dari segi usia, gaya berpakaian dan konten yang disajikan sehariharinya menjadi penilaian dalam memilih influencer. "Saya selau memilih influencer yang sering sharing konten bermanfaat sehingga saya yakin followers-nya pun bekualitas dan aktif mengikuti. Saya menilai kualitas konten mereka bisa jadi ukuran bahwa followers-nya akan memberikan feedback setelah melihat endorse," terang Valeria. Dapat disimpulkan, kredibilitas influencer yang berperan sebagai komunikator eWOM sangat penting untuk diperhatikan. Hal ini sesuai dengan yang diungkapkan Cheung \& Thadani (2012) bahwa beberapa indikator komunikator eWOM yaitu: kredibilitas sumber, daya tarik, pengungkapan identitas, kesamaan lokasi geografis, keterikatan sosial, dan homofili sosial (social homophily). Valeria memilih sumber yang identitasnya diketahui, memiliki konten dan gaya yang sesuai, serta punya keterikatan dengan pengikutnya sehingga membentuk homofili sosial (merasa memiliki kesamaan karakter). Dengan demikian, pesan yang disampaikan oleh influencer akan lebih mudah dicerna oleh khalayak.

Dalam memilih influencer, Valeria memilih yang memiliki konten berkualitas dan memiliki gaya yang bagus. Selain itu, pertimbangan jumlah pengikut juga menentukan apakah Valeria mau bekerja sama dengan influencer tersebut atau tidak. "Bukan sekedar follower ya, soalnya kan sekarang banyak orang beli follower. Saya cari yang memang punya follower aktif," jelas Valeria. Hal ini sejalan dengan pernyataan Uzunoğlu \& Misci Kip (2014) tentang poin penting influencer, yaitu: (1) Relevansi: bagaimana influencer bisa mendukung komunikasi sebuah merek, (2) Tone of voice: nilai influencer sejalan dengan merek, (3) Pengikut: jumlah pengikut yang dimiliki, (4) Konten: ketertarikan influencer dan pengikutnya, (5) Reliabilitas: bagaimana kepercayaan pengikut terhadap influencer, 
(6) Popularitas: khalayak cenderung mencari influencer yang memiliki eksposur tinggi.

Mengenai peran influencer dalam meningkatkan persepsi merek juga sejalan dengan Teori Kredibilitas Sumber. Dalam teori ini dijelaskan faktor paling penting dari kredibilitas sumber yang mengarah pada persepsi kredibilitas adalah keahlian (expertise) dan kepercayaan (trustworthiness) (Rahim et al., 2016). Sebuah bisnis yang ingin mengiklan mau membayar dengan harga tinggi dalam kesepakatan promosi karena para influencer diasumsikan sebagai role model di mata para konsumen yang sehari-harinya berkeinginan untuk bisa seperti mereka (Umeogu, 2012). Dalam dunia periklanan, kredibilitas yang dimaksud mengacu pada persepsi seseorang tentang kebenaran informasi yang diberikan oleh komunikatornya.

Mereka yang memiliki gaya yang bagus bisa digolongkan pada persepsi kredibilitas keahlian. Hal ini karena sebagai merek busana wanita, salah satu keahlian yang diharapkan hadir dalam influencer di samping keahlian promosi adalah bagaimana mereka mampu membawakan pakaian sehingga menarik minat konsumen. Ketika influencer memang memiliki keahlian di bidang fashion, mereka cenderung mampu memberikan informasi lengkap terkait produk. Penelitian pada sejumlah eWOM menunjukkan bahwa ulasan berkualitas tinggi mampu menyoroti detail penting sehingga menciptakan pemahaman yang lebih mendalam terkait produk dan layanan, sehingga mempengaruhi kognisi konsumen (Liu, 2006). Keahlian influencer dalam menyampaikan informasi produk menjadi pertimbangan utama, salah satunya dilihat dari bagaimana cara mereka membuat konten di Instagram sehariharinya. Berdasarkan keterangan Valeria, influencer harus mampu menerangkan produk dengan benar kepada konsumen. "Kami minta untuk menjelaskan karakteristik bahan, dan menjelaskan bahwa produk kami merupakan produk lokal buatan pengrajin-pengrajin batik dan penjahit rumahan," katanya.

Pada akhirnya, persepsi kredibilitas keahlian ini akan membentuk kepercayaan. Untuk membangun kepercayaan, harus ada hubungan yang berarti atau cocok, antara influencer, khalayak, dan produk (Umeogu, 2012). Influencer yang kerap memberikan ulasan detail dan visual yang baik, serta sering memberikan konten bermanfaat, tentu akan lebih mudah mendapatkan kepercayaan dari khalayak. Kepercayaan ini membantu pembentukan pemaknaan yang tepat serta loyalitas (keinginan untuk menjadi pelanggan). Salah satu komponen penting dalam persepsi merek adalah loyalitas dan kecenderungan terhadap merek (Tengblad-Kreft et al., 2017). Penelitian sebelumnya terkait persepsi merek 
menunjukkan, konsumen tidak hanya memiliki perhatian pada fitur dari merek tetapi juga aspek relasional dan emosionalnya (Aiswarya \& Krishnan, 2019). Hal penting dari persepsi merek ini tidak semata-mata hanya terkait dengan meningkatnya keinginan untuk membeli produk, melainkan juga bagaimana konsumen memahami merek. Persepsi merek adalah apa yang dipikirkan atau dirasakan konsumen mengenai sebuah merek.

"Ada yang koleksi lebih dari 8 baju karena selalu puas, dan juga tertarik karena dipakai influencer A atau B. Namun, untuk pembelian berkelanjutan biasanya memang karena konsumen sudah suka dengan kualitas produk, bukan lagi hanya karena di-review oleh influencer," jelas Valeria.

Hal ini menunjukkan, influencer punya peran penting dalam membentuk loyalitas konsumen terhadap merek. Lebih jauh dari itu, seorang influencer pun bisa memengaruhi influencer lainnya untuk membeli sebuah produk. Dengan demikian, semakin luas pula jangkauan khalayaknya kelak.

Ketepatan informasi, seperti yang diharapkan dalam pembentukan persepsi merek, salah satunya bisa dilihat dari bagaimana khalayak sebagai calon konsumen menanggapi pesan tersebut. Ketika informasi yang didapat melalui media sosial Instagram dan influencer mampu membuat khalayak memahami detail produk, harga, dan kualitas, hingga akhirnya mau membeli sebuah produk, itu berarti telah terjadi eWOM positif di dalamnya. Umeogu (2012) mengatakan, perlu ada kepercayaan antara khalayak dan influencer untuk kemudian membangun kepercayaan antara khalayak dan produknya. Dalam Teori Kredibilitas Sumber dijelaskan, untuk membangun kepercayaan, harus ada hubungan yang berarti atau cocok, antara influencer, khalayak, dan produk.

Hal ini sejalan dengan yang dinyatakan Valeria melalui wawancara. Bisa dikatakan, salah satu kontributor terbesar bagi kesuksesan promosi Celosia Etnik adalah influencer. Maka dari penjelasan di atas, untuk menciptakan eWOM positif, terbukti bahwa peran influencer sangat besar, dengan catatan harus mempertimbangkan kredibilitas dan kesesuaian dengan produk yang dipromosikan agar pesan tepat sasaran. Kredibilitas influencer akan mempengaruhi dimensi-dimensi yang seharusnya muncul dalam eWOM positif. Pada akhirnya, ketika dimensi-dimensi eWOM positif tercapai, secara langsung hal tersebut akan meningkatkan persepsi merek. Sehingga, yang didapatkan oleh pelaku bisnis adalah sampainya informasi kepada khalayak mengenai produk serta munculnya keinginan khalayak untuk melakukan pembelian.

Hasil penelitian di atas menimbulkan konsep berikutnya mengenai bagaimana influencer bisa difungsikan seperti PR dalam sebuah perusahaan. Hal ini seperti yang 
dijelaskan Valeria, "Benar, influencer bisa diibaratkan seperti PR namun untuk usaha kecil seperti ini, dia yang bantu buat publikasinya lah. Bantu approach masyarakatnya langsung. Makanya pinter-pinter pilih influencer supaya pas sama produk kita, jadi kalau mereka rekomendasiin sesuatu, dan followers-nya tau kalau itu bidangnya, pasti bakal terpengaruh. Plus, mereka mempunyai followers yang biasanya lumayan banyak juga."

Namun untuk saat ini, hal ini hanya bisa berlaku pada usaha-usaha kecil dan menengah, atau usaha milik perseorangan. Hal ini karena pada dasarnya, PR merupakan alat manajemen yang dihadirkan untuk mendukung baik dari segi internal maupun eksternal (Cornellissen, 2013). Hal ini berarti, untuk perusahaan besar, belum memungkinkan untuk hanya memberdayakan influencer dalam meningkatkan persepsi merek. Hal ini karena influencer tidak akan mengenal seluk-beluk internal perusahaan seperti yang harus dipahami seorang praktisi PR. Mereka akan lebih condong pada kegiatan eksternalnya saja.

\section{SIMPULAN}

Berdasarkan studi ini, disimpulkan bahwa peran influencer sangat penting dalam pembentukan eWOM di tengah masyarakat, yang pada akhirnya akan meningkatkan persepsi merek. Hal ini menjawab tujuan dari studi yang ingin melihat peran influencer dalam proses eWOM untuk meningkatkan persepsi merek. Seperti yang dijelaskan pada studi-studi terdahulu, eWOM dikenal memiliki kekuatan khususnya pada bidang pemasaran. Ketika bentuk strategi pemasaran ini digunakan di situs media sosial, peningkatan yang signifikan dalam efeknya terlihat jelas. Pelaku bisnis melihat eWOM yang bersifat positif merupakan salah satu kunci kesuksesan bisnisnya, terkhusus dalam ranah daring.

Sebuah eWOM positif terbentuk jika kesemua dimensi tercapai, yaitu: messageinvolvement (Dichter, 1966; Jeong \& Jang, 2011); concern for others (Engel et al., 1993; Jeong \& Jang, 2011); helping the company (Jeong \& Jang, 2011; Sundaram et al., 1998); platform assistance (Hasan, 2015; Jeong \& Jang, 2011); relevance (Lugina, 2015); timeliness (Lugina, 2015); accuracy (Lugina, 2015); dan comprehensiveness (Lugina, 2015). Studi ini menunjukkan, terpenuhinya dimensidimensi pada eWOM positif berdampak positif pada perkembangan bisnis mereka, khususnya dalam penyampaian informasi produk yang mendorong keinginan membeli dari khalayak. Namun demikian, untuk mencapai eWOM positif, kehadiran influencer memegang peranan kunci.

Penting dan signifikannya peran influencer dalam meningkatkan persepsi merek tentu 
dengan catatan. Influencer sebagai komunikator eWOM harus memenuhi kredibilitas, seperti yang diungkapkan oleh Cheung \& Thadani (2012). Berdasarkan Teori Kredibilittas Sumber, faktor paling penting dari kredibilitas sumber adalah keahlian dan kepercayaan (Rahim et al., 2016). Keahlian ditunjukkan dari kognisi influencer terhadap produk dan kepercayaan terbentuk ketika influencer sudah diakui keahliannya. Kepercayaan sendiri merupakan salah satu komponen penting dalam persepsi merek. Kepercayaan ini lebih mudah terbentuk jika ada kesesuaian antara influencer, khalayak, dan produk. Kepercayaan ini membantu pembentukan pemaknaan yang tepat serta loyalitas (keinginan untuk menjadi pelanggan). Salah satu komponen penting dalam persepsi merek adalah loyalitas dan kecenderungan memahami sebuah merek (Tengblad-Kreft et al., 2017).

Disimpulkan pula, kredibilitas influencer sangat mempengaruhi terbentuknya dimensidimensi pada eWOM positif. Saat dimensidimensi eWOM positif tercapai dan berjalan sesuai keinginan pelaku bisnis, secara langsung hal tersebut akan meningkatkan persepsi merek. Sehingga, yang didapatkan oleh pelaku bisnis adalah sampainya informasi kepada khalayak mengenai produk serta munculnya keinginan khalayak untuk melakukan pembelian.

Penelitian ini tentu tidak terlepas dari keterbatasan. Keterbatasan yang pertama adalah peneliti hanya memfokuskan hasil penelitian dari kaca mata pelaku bisnis. Dengan demikian, penelitian ini hanya bisa melihat keberhasilan penggunaan influencer dalam membentuk eWOM positif dari hasil yang dirasakan oleh pelaku bisnis saja. Penelitian ini belum bisa mengkaji lebih mendalam dari sisi khalayak untuk melihat apakah benar seorang influencer mampu menyampaikan informasi produk dengan baik dan bisa memengaruhi keinginan untuk melakukan pembelian. Keterbatasan berikutnya adalah penelitian ini dilakukan secara kualitatif sehingga hasilnya belum tentu dapat digeneralisasikan. Kemudian, penelitian ini hanya dilakukan pada ranah perusahaan perseorangan. Dengan demikian, untuk menggali data mengenai kemungkinan influencer mampu mengerjakan fungsi PR tidak bisa dilakukan lebih dalam. Hal ini karena secara perusahaan, Celosia Etnik belum membutuhkan PR untuk membantu kinerja usahanya.

Maka, untuk memperdalam penelitian, disarankan penelitian di masa depan untuk melihat keberhasilan influencer membentuk persepsi merek dari sisi khalayaknya. Hal ini untuk menggali lebih dalam apakah khalayak memang mudah terpengaruh informasi influencer. Kemudian, untuk dapat membuat generalisasi dari hasil penelitian khususnya dengan khalayak sebagai objek penelitiannya, 
disarankan untuk membuat penelitian secara kuantitatif. Penelitian selanjutnya juga bisa lebih melakukan fokus pada kaitan antara pekerjaan influencer dengan PR, dengan memilih perusahaan besar sebagai subjek penelitiannya.

Meskipun memiliki keterbatasan, penemuan dari penelitian ini tetap mampu berkontribusi dalam memperkaya penelitian di bidang komunikasi. Hasil temuan penelitian ini bisa menjadi bahan kajian baru bagi usaha yang dimaksud (Celosia Etnik) dalam memperkuat strategi pemilihan influencer di kemudian hari. Temuan penelitian ini juga bisa menjadi masukan terkait strategi promosi bagi perusahaan lain yang hendak menjalankan bisnis secara perorangan.

\section{DAFTAR PUSTAKA}

Aiswarya, G., \& Krishnan, J. (2019). Brand perception: How is it created? how does it affect the buying process? an empirical analysis on apparel brands. International Journal of Innovative Technology and Exploring Engineering (IJITEE), 8(6S), 500-504.

Carlson, B. D., \& Donavan, D. T. (2013). Human Brands in Sport: Athlete Brand Personality and Identification. Journal of Sport Management, 27(3), 193-206. https://doi.org/10.1123/jsm.27.3.193

Casaló, L. V., Flavián, C., \& Ibáñez-Sánchez, S. (2020). Influencers on Instagram: Antecedents and consequences of opinion leadership. Journal of Business Research,
117, 510-519. https://doi.org/10.1016/j. jbusres.2018.07.005

Chakraborty, U., \& Bhat, S. (2018). Online reviews and its impact on brand equity. International Journal of Internet Marketing and Advertising, 12(2), 159. https://doi. org/10.1504/IJIMA.2018.090953

Cheung, C. M., \& Thadani, D. (2012). The impact of electronic word-of-mouth communication: A literature analysis and integrative model. Decision Support Systems, 50(1), 461-470. https://doi. org/10.1016/j.dss.2012.06.008

Christensen, M., Welch, A., \& Barr, J. (2017). Husserlian Descriptive Phenomenology: A review of intentionality, reduction and the natural attitude. Journal of Nursing Education and Practice, 7(8), 113. https:// doi.org/10.5430/jnep.v7n8p113

Cornellissen, J. (2013). Corporate Communication. New York: Sage Publications.

Dessart, L., Veloutsou, C., \& Morgan-Thomas, A. (2015). Consumer engagement in online brand communities: A social media perspective. Journal of Product and Brand Management, 24(1), 28-42. https://doi. org/10.1108/JPBM-06-2014-0635

Dichter, E. (1966). How Word-of-Mouth Advertising Works. Harvard Business Review, 44(6), 147-166.

Duffy, A. M. (2015). The road more travelled: How user-generated content can lead to homogenized travel journalism. Continuum, 29(6), 1-12. https://doi.org/10. 1080/10304312.2015.1073686

Engel, J. F., Blackwell, R. D., \& Miniard, P. W. (1993). Consumer Behavior (8th ed.). Chicago: Dryden Press.

Given, L. (2008). The SAGE Encyclopedia of QUALITATIVE RESEARCH METHODS. 
UKL SAGE Publications, Inc.

Goodman, M. B., Booth, N., \& Matic, J. A. (2011). Mapping and leveraging influencers in social media to shape corporate brand perceptions. Corporate Communications: An International Journal, 16(3), 184-191. https://doi. org/10.1108/13563281111156853

Hasan, A. (2015). Pengaruh Electronic Word Of Mouth Pada Media Sosial Facebook Terhadap Keputusan Berkunjung Ke Desa Wisata Nglanggeran Gunungkidul. Jurnal Media Wisata, 13(1), 224-238. https://doi. org/10.1017/CBO9781107415324.004

Huete-Alcocer, N. (2017). A literature review of word of mouth and electronic word of mouth: Implications for consumer behavior. Frontiers in Physiology, 8, 1256. https://doi.org/10.3389/fpsyg.2017.01256

Ismail, T. A., \& Ahmad, J. H. (2015). Public Relations Vs. Advertising. Jurnal Komunikasi Malaysian Journal of Communication, 31(2), 117-130. https:// doi.org/10.17576/JKMJC-2015-3102-08

Jeong, E. H., \& Jang, S. C. S. (2011). Restaurant experiences triggering positive electronic word-of-mouth (eWOM) motivations. International Journal of Hospitality Management, 30(2), 356-366. https://doi. org/10.1016/j.ijhm.2010.08.005

Kapferer, J. (2012). The new strategic brand management (5th ed.). London: Kogan Page.

Kassim, N., \& Asiah Abdullah, nor. (2010). The effect of perceived service quality dimensions on customer satisfaction, trust, and loyalty in e-commerce settings: A cross cultural analysis. Asia Pacific Journal of Marketing and Logistics, 22(3), 351-371. https://doi. org/10.1108/13555851011062269
Katz, E., \& Lazarsfeld, P. F. (1966). Personal Influence: The Part Played by People in the Flow of Mass Communications. New Jersey: Transaction Publishers.

Kelly, M., Dowling, M., \& Millar, M. (2018). The search for understanding: The role of paradigms. Nurse Researcher, 25(4), 9-13. https://doi.org/10.7748/nr.2018.e1499

Kim, Y. S., \& Tran, V. L. (2013). Assessing the ripple effects of online opinion leaders with trust and distrust metrics. Expert Systems with Applications, 40(9), 3500-3511. https://doi.org/10.1016/j.eswa.2012.12.058

King, R. A., Racherla, P., \& Bush, V. D. (2014). What we know and don't know about online word-of-mouth: A review and synthesis of the literature. Journal of Interactive Marketing, 28(3), 167-183. https://doi. org/10.1016/j.intmar.2014.02.001

Kotler, P., \& Armstrong, G. (2006). Principles of Marketing (10th ed.). New Jersey: Pearson Education, Inc.

Ku, Y. C., Wei, C. P., \& Hsiao, H. W. (2012). To whom should i listen? Finding reputable reviewers in opinion-sharing communities. Decision Support Systems, 53(3), 534-542. https://doi.org/10.1016/j.dss.2012.03.003

Law, R., Buhalis, D., \& Cobanoglu, C. (2014). Progress on information and communication technologies in hospitality and tourism. International Journal of Contemporary Hospitality Management, 26(5), 727-750. https://doi.org/10.1108/ IJCHM-08-2013-0367

Lin, C. A., \& Xu, X. (2017). Effectiveness of online consumer reviews: The influence of valence, reviewer ethnicity, social distance and source trustworthiness. Internet Research, 27(2), 362-380. https://doi. org/10.1108/IntR-01-2016-0017

Liu, Y. (2006). Word of mouth for movies: Its 
dynamics and impact on box office revenue. Journal of Marketing, 70(3), 74-89.

Lugina, A. (2015). Pengaruh Electronic Word Of Mouth Terhadap Brand Awareness Konsumen Roti Gempol. E-Proceeding of Management, 2(3), 2779-2786.

Maslowska, E., Malthouse, E. C., \& Bernritter, S. F. (2017). Too good to be true: The role of online reviews' features in probability to buy. International Journal of Advertising, 36(1), 142-163. https://doi.org/10.1080/02 650487.2016.1195622

McMullan, J. (2020). A new understanding of 'New Media': Online platforms as digital mediums. Convergence, 26(2), 287-301. https://doi. org/10.1177/1354856517738159

Mehyar, H., Saeed, M., Al-Ja'afreh, H. B. A., \& Al-Adaileh, R. (2020). The impact of electronic word of mouth on consumers purchasing intention. Journal of Theoretical and Applied Information Technology, 98(2), 183-193.

Moleong, L. (2004). Metodologi Penelitian Kualitatif. Bandung: Remaja Rosdakarya. Mulawarman, M., \& Nurfitri, A. D. (2017). Perilaku Pengguna Media Sosial beserta Implikasinya Ditinjau dari Perspektif Psikologi Sosial Terapan. Buletin Psikologi, 25(1), 36-44. https://doi.org/10.22146/ buletinpsikologi.22759

Nieto, J., Muñoz-Gallego, P. A., \& HernándezMaestro, R. M. (2014). Marketing decisions, customer reviews, and business performance: The use of the Toprural website by Spanish rural lodging establishments. Tourism Management, 45, 115-123. https://doi.org/10.1016/j. tourman.2014.03.009

Olmedilla, M., Arenas-Márquez, F. J., MartinezTorres, M. R., \& Toral, S. L. (2016).
Identification of Influencers in eWord-ofMouth communities using their Online Participation Features. 38-45. https://doi. org/10.4995/carma2016.2016.3642

Olshavsky, R. W., \& Rosen, D. L. (1985). Use of Product-Testing Organizations' Recommendations as a Strategy for Choice Simplification. The Journal of Consumer Affairs, 19(1), 118-139. https://doi. org/10.1111/j.1745-6606.1985.tb00347.x

Rahim, R. A., Sulaiman, Z., Chin, T. A., Baharun, R., \& Muharam, F. M. (2016). Measuring electronic word of mouth review adoption on green purchase intention using source credibility theory. Advanced Science Letters, 22(12), 4283-4287. https://doi. org/10.1166/asl.2016.8129

Rosario, A. B., Sotgiu, F., De Valck, K., \& Bijmolt, T. H. A. (2016). The effect of electronic word of mouth on sales: A meta-analytic review of platform, product, and metric factors. Journal of Marketing Research, 53(3), 297-318. https://doi. org/10.1509/jmr. 14.0380

Schouten, A. P., Janssen, L., \& Verspaget, M. (2019). Celebrity vs. Influencer endorsements in advertising: the role of identification, credibility, and ProductEndorser fit. International Journal of Advertising. https://doi.org/10.1080/02650 487.2019.1634898

Setyorini, D. A., \& Irwansyah, I. (2018). Managing Social Media Activist as a Crisis Management Strategy. 2nd Indonesia International Graduate Conference on Communication (Indo-IGCC) Proceeding.

Snyder, H. (2019). Literature review as a research methodology: An overview and guidelines. Journal of Business Research, 104(August), 333-339. https://doi. org/10.1016/j.jbusres.2019.07.039 
Strauss, A., \& Corbin, J. (1990). Basics of qualitative research: Grounded theory procedures and techniques. New York: Sage Publications, Inc.

Sugiyono. (2012). Metode Penelitian Kuantitatif, Kualitatif dan R\&D. Bandung: Alfabeta.

Sundaram, D. S., Mitra, K., \& Webster, C. (1998). Word-Of-Mouth Communications: a Motivational Analysis. NA - Advances in Consumer Research, 25, 527-531.

Talwar, M., Talwar, S., Kaur, P., Islam, A. K. M. N., \& Dhir, A. (2020). Positive and negative word of mouth (WOM) are not necessarily opposites: Areappraisal using the dual factor theory. Journal of Retailing and Consumer Services, September, 102396. https://doi. org/10.1016/j.jretconser.2020.102396

Tengblad-Kreft, V. A. J., Hagman, A. M., \& Hessels, E. (2017). Influencer marketing and the effect on brand personality and brand perception. Strategic Brand
Management Master Papers.

Umeogu, B. (2012). Source Credibility: A Philosophical Analysis. Open Journal of Philosophy, 2(2), 112-115. https://doi. org/10.4236/ojpp.2012.22017

Uzunoğlu, E., \& Misci Kip, S. (2014). Brand communication through digital influencers: Leveraging blogger engagement. International Journal of Information Management, 34(5), 592-602. https://doi. org/10.1016/j.ijinfomgt.2014.04.007

Webster, J. G., \& Watson, R. T. (2002). Analyzing the past to prepare for the future: Writing a literature review. MIS Quarterly, 26(2), xiii-Xxiii. https://doi.org/10.2307/4132319 Yang, F. X. (2017). Effects of Restaurant Satisfaction and Knowledge Sharing Motivation on eWOM Intentions: The Moderating Role of Technology Acceptance Factors. Journal of Hospitality and Tourism Research, 41(1), 93-127. https://doi. org/10.1177/1096348013515918 